\title{
14. Resilience in its Historical and Contemporary Contexts
}

\author{
David Kirk
}

This contribution focuses on the concept of resilience as it is understood and used in a wide range of contexts. As a trained medical doctor, I graduated from the Otago Medical School in 1985. I therefore have some understanding of the resilience of the human body and mind. I also have experience as a professional rugby union player. My sporting experiences have given me insight into the resilience of sports teams.

I have a reasonable understanding of economics from later study in Oxford and am therefore able to say something about resilient economic systems. Some of you may also know I worked in Wellington in the office of the prime minister Jim Bolger for more than three years. In its second term, his government had a one-seat majority but survived the term, so I have some insight into the resilience of governments.

Most of my working life, however, has been in business management. I have worked in the oil and gas industry, in the pulp and paper business, in printing and media services, in newspaper and magazine publishing and in a wide range of Internet-related businesses. I am currently involved in the film entertainment business, the e-commerce business, the funds management and broking business, and I am the co-founder and managing partner of a technology investment firm. I therefore am able to say something about the resilience of firms and industries from firsthand experience.

I will begin by discussing the resilience of political institutions and processes. It is important, however, to understand that my belief about resilience is that it is, in all contexts, a function of redundancy and optionality.

\section{Political Philosophy and the Configuration of Political Institutions}

There are two long periods and one short period in the evolution of the political institutions and processes of which we are the inheritors (this is, of course, a simplification, but a necessary one given the limited scope of this chapter). The documented development of Western liberal political tradition began in Greece about 500 or 600 years before the birth of Christ and continues today. 
This first period is what we call Antiquity. There is no defined end to this period but it is not uncommon to consider the emperor Justinian's closure of the Neoplatonic Academy in Athens in 529 AD-because he considered its teachings to be inconsistent with Christianity - as the date marking the end of Antiquity.

The political institutions of the Greek city-states, of Alexander's empire and of the Roman Republic and later the Roman Empire operated effectively, and proved themselves resilient, for a little more than a millennium. There was, of course, a great deal of disorder and change in the detail of the governance arrangements during this period, but it was a period in which art, philosophy, commerce, science and culture generally developed consistently and spread widely. It was therefore a long period in which political and administrative processes broadly worked to the benefit of the peoples of Europe.

The second long period in the development of Western political institutions and processes also lasted about 1000 years. This was the period we call the Middle Ages. The Middle Ages was a period in which Christianity was the dominant impulse in art, science, military matters and politics in all of Europe, from the cold north to the Mediterranean and extending east to Constantinople and the reaches of the Byzantine Empire.

During the Middle Ages, God's will determined all. Only God was not around to interpret His own will, so that difficult task fell to the Pope and his armies and to the kings and their armies. Life for everyone else was short, unpleasant and subject to sudden disaster. A noble family's squabble might result in the razing of your house and confiscation of your fields, or if you were at court quickly shifting alliances could result in your head appearing on a spike one fine morning. But no-one was allowed to consider the ghastly unpredictability of life in the Middle Ages as in any way arbitrary. It was, after all, God's will.

The sole source of goodness and authority was infallible and He had a plan and the Pope and the kings knew what that plan was: it was for them to rule. The doctrine of the divine right of kings and the ceding of temporal power to popes and other high ecclesiasticals, whose playbook was Scripture and personal revelation, worked to provide stable and reasonably resilient governance so long as the people were not completely starving and the authority's armies were strong. Religious faith was a source of personal and institutional resilience through the Middle Ages but it was also the source of much instability. Political instability in the Middle Ages was chronic because no-one really knew whose side God was on. Anyone who made a claim of divine inspiration and could raise an army devoted resources to war. Agreeing to differ was not an option. There could only be one divine truth and only war would determine who had it. 
The poor serf or impoverished city-dweller at least had the hope of salvation in the next life. And Scripture made it fairly plain that the winners on Earth were likely to get their comeuppance in the next world. Schadenfreude, even if it was postponed, worked wonders as a spiritual salve in the Middle Ages. Dante Alighieri gave the best literary expression to the sentiment that must have fuelled the resilience of all of downtrodden Europe throughout the Middle Ages. This is from The Inferno:

And so we passed along from bridge to bridge,

With other talk, whereof my Comedy

Cares not to tell, until we topped the ridge ...

So not by fire, but by the art divine,

A thick pitch boiled down there, spattering the brink

With viscous glue; I saw this, but therein

Nothing; only great bubbles black as ink

Would rise and burst there; or the seething tide

Heave up all over, and settle again, and sink.

And while I stood intent to gaze, my guide,

Suddenly crying to me, 'Look out! Look Out!'

Caught me where I stood and pulled me to his side ...

And then behind us I beheld a grim

Black fiend come over the rock-ridge at a run ...

On high-hunched shoulders he was carrying

A wretched sinner, hoist by haunch and hip.

Clutching each ankle by the sinew-string.

'Bridge-ho!' he bawled, 'Our own Hellrakership!

Here's an alderman of St Zita's coming down;

Go souse him, while I make another trip ...'

He tossed him in, and over the flinty cliff

Wheeled off ...

Down bobbed the sinner, then up in writhing knot.

(The Divine Comedy: Inferno, Canto XXI)

The third period of political organisation and philosophy is relatively short. Observations of the natural world from which could be discerned cause and effect led to explanations of natural phenomena according to the laws of nature. 
Predictions from these natural laws proved to be accurate and the authority of the Scriptures and God began to unravel. It did not matter that the Inquisition extracted a recantation from Galileo; it was a demonstrable fact that the Earth revolved around the Sun and so it would ever be.

It took nearly another century to conclude the process, but man-discovered laws governing the physical world were the natural precursor to man-created laws governing the constitutional and political worlds.

The 'Glorious Revolution' of 1688, the American Declaration of Independence, the proclamation of the rights of man, the doctrine of the separation of powers and all the institutional forms established as a result of these constitute our modern Western political systems.

All of the understandings of modern democratic government were in place by the end of the eighteenth century but that does not mean it was straightforward to give these understandings stable institutional form. Take France for instance. France is often considered the source of modern democratic ideas and impulses; however, the implementation of these impulses has proved to be problematic in France. In a nation in which rhetoric is sometimes inclined to exceed rigour, we should perhaps not be surprised that after the revolution came Napoleon and then an alternating stream of republic, empire, restoration, empire and then two more republics before the fifth and current republic emerged in 1958.

Germany declared itself a republic only in 1918 and in the east of the continent it was not until 1992 that the Russian Federation came into being and democratic processes and institutions were established.

It is only now, at the end of the twentieth century and the beginning of the twenty-first century, that we have, in most of Europe and in a variety of the colonies and other countries that the European powers occupied in the nineteenth century, the 'best' form of government. I put 'best' in inverted commas because we ought to ask why it is we consider the political institutions we currently have to be the best.

First, I think it is because we gradually invented them and everyone always likes best those institutions of which they feel they have some ownership. Second, it is because they are extant and have survived and no-one likes to think they live in a second-best world or under second-best conditions.

Third, and this is a better reason, it is because others are actively choosing them. Eastern Europe has recently chosen, in a variety of forms, representative democracy. Even Russia has chosen representative democracy. Unfortunately, 
the leaders of Russia and the very rich have chosen not to implement the system, but they have it nominally. Closer to home Timor-Leste and Burma are choosing Western-style political institutions and processes.

The fundamental reason why, finally, after 2500 years, we think we have arrived at the right combination of political processes and political institutions is, however, because these processes and institutions are consistent with our idea of the best political philosophy, which is a messy and shifting trade-off between individual freedom and a belief in human equality.

But if we look back to earlier times we can see that this consistency was always a feature of political regimes. Political processes and political institutions are always consistent with the prevailing ideal political philosophy. I would go so far as to say that, if they are not, they have no resilience at all.

Ancient Sparta had a different political philosophy to Athens. Athens had a different philosophy in the time of Pericles than in the time of Alexander. The philosophy of the Roman Republic differed from the philosophy of the Roman Empire. But while there were stable governance arrangements there was always an alignment between the political, and we could say just as easily ethical, philosophy of the people and those arrangements.

In the time of Marcus Aurelius (who died in 180 AD), the dominant personal and therefore political ethic in the rulers of the Empire was Stoicism. Courage, wisdom, temperance and justice were the chief Stoic virtues and lawmaking processes and their application were supposed to be consistent with these virtues.

In his Meditations, Marcus Aurelius summed up the Stoic's approach to the new day thus:

Begin each day by telling yourself: Today I shall be meeting with interference, ingratitude, insolence, disloyalty, ill-will, and selfishnessall of them are due to the offender's ignorance of what is good and evil. But for my part I have long perceived the nature of good and its nobility, and the nature of evil and its meanness ... therefore none of these things can injure me, for nobody can implicate me in what is degrading.

Well, that at least proves that not as much has changed in 2000 years as we would like to think!

The same consistency is true of the Middle Ages. Political institutions and processes were consistent with the ethical, and in this case religious, beliefs of the people. Middle Agers, if we can apply that term to a millennium as well as populations, believed God was the source of all authority and therefore His representatives should have authority on Earth. 
A more modern example is communism, which lasted in Eastern Europe for about 70 years. It was another attempt to build political (and economic) institutions and processes consistent with a political philosophy. In essence communism is a throwback to a medieval religion-based system, only the God of the Middle Ages is replaced in theory with the dictatorship of the proletariat and in practice by a common-or-garden dictator and a sophisticated police state. I have often wondered if the mistake they made was to leave out some promise of life after death. I think it was the atheism that got them in the end. After all, if the economic system does not work to make life comfortable for the people and there is no hope of a better life after this, there is not a lot to lose by rejecting what you have.

\section{The Characteristics of Resilience}

The aforementioned historical overview is relevant to the modern governance problem of resilience. An important question to ask ourselves is what reasons do we have to believe that our current system of governance is resilient? After all, the ancient systems lasted 1000 years and those of the Middle Ages about the same time, whereas we moderns have been struggling along for only a few hundred years.

The first point I will make is that no system is resilient when people are starving. This is the extreme case, but more generally the point is that no system is resilient when the economy is failing to improve the livelihoods of the majority of the people.

I chose the phrase 'failing to improve' because an important part of the personal philosophy of the modern age is the notion of progress. This is partly a Christian concept - we are all progressing towards salvation or damnation - and partly an Enlightenment concept. Science in particular has given us the capacity to understand and modify our world. This has not always been for the better, but much technological advancement has made life more interesting and more comfortable for us. And successive generations being better entertained and better fed and living longer have ingrained in us the belief that progress is good.

At its most basic, and therefore at its most politically powerful, progress is about getting richer. There are two ways in which people in a certain country can get richer. One is that the whole country can get richer and they, like the proverbial boat on the rising tide, can rise with the general wealth accumulation, and the second is even if the whole country is not getting richer, so long as you can get a greater share of what is available you can be richer, albeit not now in concert with others but at the expense of others. 
I have already answered the question regarding what produces resilience in a person, a business, an economy or a political system. If an economy is growing strongly it is increasing its redundancy (its spare capacities). Redundancy might be captured by the private sector as more plant and equipment, or higher retained earnings and less debt, or it might be captured by the public sector in the form of improvements in the quality of services or an improved fiscal position. In any event, the point is there is a greater capacity for the system to either invest in further growth creation (and so continue to get richer) or distribute the available wealth to people who are not 'progressing' - that is, those who are not getting richer.

This capacity either to invest or to distribute, of course, relates to optionality (the creation of further choices). Redundancy almost always contributes to the creation of optionality. In this way you can see that redundancy and optionality are not separate but are related elements in understanding resilience.

Resilient political systems must improve the livelihoods of the majority of the people if they are to survive. This is true in the medium term, but I accept that in the short term people will put up with a great deal of hardship and not throw out the political system. This is true largely because the collective prevailing political philosophy, which in our modern case is a belief in freedom and a form of equality, continues to be consistent with the political institutions and processes of the country. It is just that the politicians are useless. And there is a mechanism for dealing with that.

The heart of the resilience of representative democracy are periodic elections, and periodic elections are of course an optionality. This optionality only has value, however, if it results in some change for the better. We can chop and change our governments as much as we like but, if the next lot is as bad as the last lot and the one after that is no better, sooner or later something has to give. These are the circumstances in which democracy has been shown to fail in the past and a new form of government has been tried.

I am not saying that any of the major Western democracies is in danger of being overthrown any time soon but I do say that the United States and Europe in particular have precious little redundancy and that the value of the option of periodic elections is far lower today than it has been in the past. I am saying that representative democracy in the United States and Europe is far less resilient today than it has been at any time since the 1930s.

It is often not easy to recognise the signs of a lack of resilience. Consider, for example, the question of whether Germany today is more resilient that Greece. The popular response would be that Germany is obviously more resilient than 
Greece. Greece, after all, is nearly bankrupt. It is a country burdened with huge public sector debt, dependent on Europe and particularly the powerful and resilient German economy for loans to prevent economic and social collapse.

Germany, on the other hand, appears to be the strongest state in Europe. The Germans pay their taxes on time, work hard, save their money and have a secure and resilient political system. German governments function effectively. German leaders are tough and resilient.

But we make a mistake if we conclude from the current situation in Europe that Germany is more resilient than Greece. I do not believe we have the evidence to draw any conclusions on this. This is because we cannot judge resilience until we apply the same stress to the two systems and the two peoples.

What if German banks had borrowed heavily in short-term loans from overseas banks and were subject to demands for repayment within 90 days? What if German banks were, as a consequence, failing? What if the unemployment rate in Germany was 33 per cent and what if the tax take was to fall so precipitously that German States did not have the money to pay unemployment benefits? And what if industrial production in Germany was to be just 40 per cent of what it had been three years previously? What then? Well then perhaps we could judge relative resilience.

But, in fact, we don't have to ask 'what if?' at all. The conditions I have described were exactly the conditions that prevailed in Weimar Germany in 1932. Thirteen years later, five million Germans were dead or missing and the country was a divided, occupied, smouldering wreck.

Of course I am not saying the same outcome would occur if the same stresses were placed on the German institutions and people today. There is no evidence for or against that proposition. But perhaps we need to give the Greeks more credit for their resilience and forbearance than we do. It is correct to conclude that public protest, even smashing things and lighting fires, is better construed as a contributor to Greek resilience than to Greek fragility.

Why? Because rioting to the Greeks is an option available to them by which they can express their frustration at the ineffectiveness of the political system and the governments it has produced.

The political system in Greece failed because governments were elected to do stupid things. They spent too much; they created an unsustainable pension system; they created an ineffective tax system. You might reasonably say it was not the Greek Government but the Greek people who were to blame. They elected these stupid governments. 
But all electorates are uninformed. All electorates are gullible. All electorates will vote for what they believe is in their short-term interests. It is human nature. It is the responsibility of those who seek election to put in front of the electorate sustainable policies. Any fool can dupe someone into electing him to office. Only a wise and courageous politician can hold his course when things go badly.

The Greeks themselves can reach back thousands of years to their own proud heritage to understand what it takes to be a real leader in difficult times. Thucydides quotes Pericles, explaining his policies at a time when the war with Sparta is going badly:

It is a policy which entails suffering, and each of you already knows what this suffering is; but its ultimate benefits are still far away and not yet clear for all to see. So, now that a great and sudden disaster has fallen on you, you have weakened in carrying out to the end the resolves which you made.

When things happen suddenly, unexpectedly, and against all calculation, it takes the heart out of a man; and this certainly has happened to you, with the plague coming on top of everything else. You must remember that you are citizens of a great city and that you were brought up in a way of life suited to her greatness; you must therefore be willing to face the greatest disasters and be determined never to sacrifice the glory that is yours. We all look with distaste on people who arrogantly pretend to a reputation to which they are not entitled; but equally to be condemned are those who, through lack of moral fibre, fail to live up to the reputation which is theirs already. Each of you, therefore, must try to stifle his own particular sorrow as he joins with the rest in working for the safety of us all.

\section{Resilience and the Political Ethic of the Populace}

So I make the point that the resilience of political systems rests finally on the political ethic of the people. Political stability rests on the redundancy a nation has in the belief and commitment of its people to the political ideals the system is designed to embody.

The redundancy in belief and commitment to the political ethic upon which Western political institutions were founded is now low in many Western nations. This sinking store of ethical legitimacy of Western governments is the result of profound changes in the economic and social conditions in these countries. 
In the United States, for instance, it seems that every week there is some commentary on the death of the American dream. The United States is a more unequal society than Australia or New Zealand, but the majority of Americans have accepted this inequality as the price of liberty. They have been told inequality is the Siamese twin of the opportunity to improve their own situation and they have believed this because, at least anecdotally, it has been true. Many people are now beginning to believe that the dream of owning a home and sending their kids to college is beyond them. And yet they see income inequality growing. The same is true in a less virulent form in Australia and New Zealand.

In Europe the resilience of individual states has been severely undermined by their lack of financial redundancy. They have simply run out of money. This has been compounded by the lack of optionality these states face as a result of their membership of the euro monetary zone. They cannot devalue their currency; they cannot manage their own monetary policy. Without redundancy and optionality, there can be no resilience.

Let me conclude this section with an analysis of the resilience of the political institutions in the three periods: Antiquity, the Middle Ages and the modern period.

The prevailing ethic in antiquity amongst the ruling classes was one form or another of personal virtue. In the Middle Ages the ethic was Christian virtue and in the modern period the ethic is, as I said earlier, a transient trade-off between freedom and equality, the result of which at any one time is a collective conception of a just society.

The political institutions of antiquity and the Middle Ages adapted and adjusted themselves to remain consistent with the political expectations of the people for more than 1000 years. It is important to clarify here that I refer to 'people' as the group who had the capacity to influence the political process.

This excludes, for instance, women, slaves, the faraway peoples in Antiquity, the disenfranchised and very poor of the Middle Ages. But the Ancients and the Middle Agers were undone in the end because their systems lacked optionality. The ethic of personal virtue, however much redundancy was built into it by the acceptance of all sorts of religious affiliation and personal philosophy, could not compete with the appeal of Christianity - the promise of life after death. Christianity outsourced virtue. God sent His son to die so that mankind could be saved and that trumped anything the ancient world could come up with.

A thousand years later, political institutions based on divinity collapsed because their system could not adapt to the newer, manmade laws and institutions. 
Representative democracy seems to have a good deal of built-in optionality. Like the ancients' systems, it is based not on one core idea. It is, instead, founded on the flexible interplay of two ideas, liberty and equality, which are themselves flexible notions. But unlike the ancients, whose ideas of virtue were founded in superstition, ancestor worship and pure thought, the modern ethic is a derivative of empiricism and, at least in part, of the scientific method. Our modern systems are pragmatic and, if we can muster the numbers, always open to change within the limits of the majority's conception of a just society. This endows much resilience.

\section{Conclusion}

Finally, then, I will furnish a few brief examples of resilience as a product of redundancy and optionality from my other areas of experience. I work from the equation that resilience equals redundancy multiplied by optionality.

The human body has a great deal of redundancy. We have two lungs, two kidneys, two eyes, two legs, two arms, 10 fingers. And we have much, much more tissue in each of our major organs than we require for simple life support. The brain is the most significant option-generating device in the human. We can think our way around all sorts of problems. We can learn new things and endlessly adapt. The human is the most wildly successful creature ever and the most resilient creature the world has ever seen, largely because it has massive redundancy and option-generating capability.

The best sports teams are the teams that can do two things: they can play a given style of game better than their opponents and they have 'something in reserve' when it is needed to get them over the line. And two, they have the capacity to play multiple styles of game depending on the prevailing weather, the strength of the opposition and the attitude of the referee, among other things.

Resilient business organisations require plenty of redundancy. There are no new ways to go broke: running out of cash remains the only one. Low debt, high margins and diversified sources of revenue are hedges against inevitable market downturns, new competition and regulatory change. But these redundancies merely delay the inevitable. If companies are not able to adapt to the new conditions, using up their redundancy to create new options for growth then they will not survive. New geographies, new products, new customers and whole new businesses are all important optionalities that firms must have or develop quickly when they are needed.

Take one example: I joined the newspaper publishing business as the CEO of Fairfax Media in late 2005. I was late. The online classified advertising businesses 
that are thriving today in Australia at the expense of the big metropolitan newspapers were already established. I invested heavily in diversifying Fairfax's revenue, most notably by buying Trade Me, New Zealand's biggest online auction and classifieds website, for what was thought at the time to be a wildly expensive price of NZ\$750 million; however, after Fairfax purchased Trade Me in 2010, the business had by then doubled in value.

The optionality I contributed to building into Fairfax has made the company more resilient, but it came at the expense of redundancy as I used up the balance sheet headroom. Ultimately, though, I had little choice. What I did has helped the company, but there remains no guarantee the business will survive in its current form. It is a competitive world in which we seek to survive and prosper, and we need to build resilience to do that. 
This text taken from Future-Proofing the State: Managing Risks, Responding to Crises and Building Resilience, edited by Jonathan Boston, John Wanna, Vic Lipski and Justin Pritchard, published May 2014 by ANU Press, The Australian National University, Canberra, Australia. 